\title{
Desamerization of Bitter Jam: Biochemical and Sensory Quality
}

\author{
Samira Lagha-Benamrouche $\mathbb{D}^{1,2,3}$ Terkia Benaissa, $^{3}$ and Rezki Sadoudi ${ }^{3}$ \\ ${ }^{1}$ Laboratory of Biochemistry, Biophysics, Biomathematics and Scientometry (3BS Laboratory), \\ Faculty of Nature and Life Sciences, Abderahmane Mira University, Bejaia 06000, Algeria \\ ${ }^{2}$ Research Laboratory Soft Technology, Valorization, Physiochemistry of Biological Materials and Biodiversité, \\ Faculty of Sciences, UMBB University, Boumerdes 35000, Algeria \\ ${ }^{3}$ Department of Biology, Faculty of Sciences, M’Hamed Bougara University, Boumerdes 035000, Algeria
}

Correspondence should be addressed to Samira Lagha-Benamrouche; benamrouchelagha@gmail.com

Received 11 March 2018; Revised 20 May 2018; Accepted 28 May 2018; Published 29 July 2018

Academic Editor: Alessandro Attanzio

Copyright () 2018 Samira Lagha-Benamrouche et al. This is an open access article distributed under the Creative Commons Attribution License, which permits unrestricted use, distribution, and reproduction in any medium, provided the original work is properly cited.

\begin{abstract}
This work consists of studying the influence of the desamerization of the mesocarpe on the chemical composition and the sensorial quality of the jam, based on the bitter orange. The results of the various analysis show that desamerization decreases acidity, sugars, protein, and bioactive compound levels (carotenoids, polyphenols, and vitamin C), but desamerized jams still remain an important source of antioxidant compounds with antioxidant potential in the diet. Concerning the sensory analysis of the jams, the results show that the jam desamerized with water presents the same bitterness as the bitter jam and that the salt significantly reduces the bitterness of the jams.
\end{abstract}

\section{Introduction}

Citrus fruits are one of the most important fruit crops in the world. They include lemons, mandarins, pomelos, cédrats, oranges, grapefruits, limes, etc. They are eaten as dessert (fresh fruit), jam or juice [1].

Citrus peel is characterized by its high content of dietary fiber (pectin, cellulose, and polysaccharides), minerals, vitamins and secondary metabolites with significant antioxidant potential and contributing to human health such as carotenoids, essential, oils and phenolic compounds [2,3]. Citrus peel is a natural source of flavonoids, in particular flavanones, flavanone glycosides, and polymethoxylated flavones, which are relatively rare in other plants [4] and are known to have anti-inflammatory and antioxidant properties [5]. The Bigarade is rarely consumed fresh because it is very acidic. The presence of certain flavonoids (neohesperidine, naringine, etc.) in the peels of the Bigarade gives the fruit a bitter taste, which is felt in the jams' preparations [6].

Jam is a means of preserving fruits, and the high sugar content of jam does not allow bacteria, yeast, and molds to grow and also prevents other spoilage. This means that the nutritional qualities of the fruits can be maintained at the same time as providing tasty products [7].

The objective of our work is to study the influence of the desamerization of mesocarpe on the chemical composition and the sensorial quality of the Bigarade jam. Our work is in line with the prospect of valorisation of the bitter orange that is exploited in Algeria only for these essential oils.

\section{Materials and Methods}

2.1. Collection of Samples. Bitter oranges (Citrus aurantium L. $\mathrm{cv}$ Bigarade) were collected in the area called Atlas Blideen or Metidjian Atlas which is a region known for the fertility of its soil and its oranges of good quality. This region is located between Blida and Bouïra, two nonremote regions located in the north center of the country. Both regions have a Mediterranean climate with a relatively cold and rainy winter and a hot and dry summer. The harvest was done in a random manner from several trees belonging to the same variety during the month of February 2016. 


\subsection{Desamerization of Peels and Preparation of Jams}

2.2.1. Desamerization. Salt, heat, and water are considered as driving elements in the operation of desamerization process. In this study, the salt factor was variable; five salt levels were fixed during this operation. They correspond to the five percentages $(0,0.3125,0.625,1.25$, and $2.5 \%)$ of salt taken according to the weight of the fruit. The peels of the fruit were cut into pieces and immersed in salt water for $5 \mathrm{hr}$ and then preheated with salt in stainless steel pot for five minutes after boiling. The hot water was poured and then replaced by cold water with the addition of salt for soaking (4 times at $5 \mathrm{hr}$ intervals).

2.2.2. Cooking. The drained peel and the cleaned fruit quarters are cut into small pieces of $2 \times 3 \mathrm{~cm}$, and the seeds are put into a small muslin bag. Weigh the fruits and take the same weight of water and 1.5 weight of sugar to prepare the syrup. The jam is cooked for 45 to $50 \mathrm{~min}$. During the boiling, temperature and sugar concentration were checked. This treatment is stopped when the concentration reaches 60-65 Brix by means of a refractometer.

\subsubsection{Physicochemical Analysis}

(1) Moisture Content. The thermal drying method was used in the determination of moisture content of the samples [8].

(2) $\mathrm{pH}$ and Titratable Acidity. The $\mathrm{pH}$ of the jams and pulps is measured using a $\mathrm{pH}$ meter. The titratable acidity is determined by neutralizing the acid present in a known amount of sample using a base $(\mathrm{NaOH})$. The evaluation is carried out by titration using a color indicator, phenolphthalein [9].

(3) Rate of Soluble Solids. Soluble solids represent all solids dissolved in water, including sugars, salts, proteins, and carboxylic acids. The rate of soluble solids, expressed in degrees Brix, is determined using a refractometer [8].

(4) Sample Defecation. The aqueous extract of sugary solutions is loaded with many substances (carbohydrates, fats and lipoids, pigments, amino acids, organic acids, mineral salts, reducing substances, which are not carbohydrates, etc.). These substances may disrupt the quantification of sugar. Defecation of samples was carried out according to the Carrez method [10].

(5) Total Sugar Content. The total sugar content was determined according to the method of Dubois [11]. Sugar concentrations are determined by referring to the standard glucose curve (10 to $80 \mu \mathrm{g} / \mathrm{ml}$ ), and the results are expressed in $\mathrm{mg}$ glucose equivalents $/ 100 \mathrm{mg}$ or $100 \mathrm{ml}$ of jam, fresh peels, or Bigarade juice.

(6) Reducing and Nonreducing Sugar Content. This method is based on the reduction of the Fehling liquor in the presence of soda by the reducing sugars present in the sample. For the nonreducing sugars, the defecated solution is hydrolyzed in an acidic and hot medium. We took a volume of this solution and then we proceeded as for reducing sugars. Hydrolysis allows us to determine the total sugars (reducing sugars + hydrolyzable sugars) and to indirectly deduce the level of nonreducing sugars (total sugars-reducing sugars) [12].

(7) Pectin Content. The pectin extraction method used is that described by Multon [13]. It is based on the principle of transformation of pectin into calcium pectate.

(8) Protein Content. The proteins were assayed according to the method of Bradford [14]. A calibration curve is established from a standard solution of BSA (10 to $90 \mu \mathrm{g} / \mathrm{ml})$.

(9) Ash Content. The determination of ash is based on the destruction of all organic matters under the effect of high temperature $\left(500 \pm 25^{\circ} \mathrm{C}\right)[15]$.

(10) Ascorbic Acid Content. The ascorbic acid content is determined according to the method of Tillmanns cited by Anonyme [16], which is based on the quantitative reduction of 2.6 DPIP (dichlorophenolindophenol) to leuco derived from the reduced form of ascorbic acid (the oxidized form of 2.6 DPIP is pink in acid medium).

(11) Carotenoids. The carotenoid content is determined by the AOAC method [17], and $\beta$-carotene was used as standard.

(12) Phenolic Compounds. Ten grams of jam were extracted with $200 \mathrm{ml}$ of methanol-water $(700: 300, \mathrm{v} / \mathrm{v})$ at room temperature for $24 \mathrm{~h}$ using a magnetic blender. Then, the extract was vacuum-filtered through sintered glass filter crucibles (porosity 3) and vacuum-filtered using Whatman No. 1 paper. The obtained aqueous organic extract was concentrated, under reduced pressure in rotary evaporation at $40^{\circ} \mathrm{C}$, until complete evaporation of organic solvent then reconstituted in pure methanol. The amount of total phenolics in the extract was determined using the Folin-Ciocalteu reagent and gallic acid as standard as described by Meyers et al. [18]. Proanthocyanidins were determined by the vanillin reagent assay according to $\mathrm{Ba}$ et al. [19], and catechin was used as standard. Colorimetric aluminum chloride method was used for flavonoids and flavonols determination, using the optimized protocols established by Bahorun et al. [20] and Kumaran and Karunakaran $[21,22]$, respectively. Quercetin was used as standard.

\subsubsection{Determination of the Antioxidant Activity}

(1) Reducing Power. The reducing power was determined according to the method of Oyaizu [23]. Quercetin and gallic acid were used for comparison.

(2) Scavenging Activity against the DPPH Radical. The stable radical 1,1-diphenyl 1-2-picrylhydrazyl (DPPH) was used for determination of free radical scavenging activity of the extracts [24]. Quercetin and gallic acid were used for comparison. 
TABLE 1: Effect of desamerization on the physicochemical characteristics of jams and comparison with parts of the fruit.

\begin{tabular}{lcccc}
\hline Jams & $\mathrm{pH}$ & Acidity $(\mathrm{g} \mathrm{CAE} / \mathrm{l})$ & Brix $(\%)$ & Moisture $(\%)$ \\
\hline Bitter & $2.80 \pm 0.00^{\mathrm{f}}$ & $27.84 \pm 0.4^{\mathrm{b}}$ & $59.67 \pm 0.58^{\text {cde }}$ & $38.433 \pm 0.09^{\mathrm{e}}$ \\
DJW & $2.87 \pm 0.05^{\mathrm{b}}$ & $24.84 \pm 0.00^{\text {cde }}$ & $59.67 \pm 2.52^{\text {cd }}$ & $39.494 \pm 0.47^{\mathrm{d}}$ \\
DJ NaCl 2.5\% & $2.84 \pm 0.01^{\mathrm{bc}}$ & $24.33 \pm 0.53^{\text {cde }}$ & $65.33 \pm 0.58^{\mathrm{a}}$ & $34.790 \pm 0.02^{\mathrm{f}}$ \\
DJ NaCl 1.25\% & $2.83 \pm 0.01^{\mathrm{bcd}}$ & $24.35 \pm 1.08^{\text {cd }}$ & $64.33 \pm 0.58^{\mathrm{ab}}$ & $36.084 \pm 1.31^{\mathrm{c}}$ \\
DJ NaCl 0.625\% & $2.84 \pm 0.01^{\mathrm{bc}}$ & $24.33 \pm 0.53^{\text {cde }}$ & $62.33 \pm 0.58^{\mathrm{c}}$ & $39.544 \pm 0.63^{\mathrm{c}}$ \\
DJ NaCl 0.3125\% & $2.82 \pm 0.01^{\mathrm{bcde}}$ & $24.96 \pm 0.57^{\mathrm{c}}$ & $64 \pm 1.00^{\mathrm{ab}}$ & $33.826 \pm 0.21^{\mathrm{g}}$ \\
Peels & $4.16 \pm 0.01^{\mathrm{a}}$ & $20.91 \pm 0.36^{\mathrm{f}}$ & $11.67 \pm 0.58^{\mathrm{f}}$ & $67.00 \pm 0.18^{\mathrm{b}}$ \\
Edible portion & $2.51 \pm 0.01^{\mathrm{g}}$ & $48.00 \pm 1.00^{\mathrm{a}}$ & $10.67 \pm 1.15^{\mathrm{fg}}$ & $89.697 \pm 0.29^{\mathrm{a}}$ \\
\hline
\end{tabular}

CAE: citric acid equivalents, DJW: desamerized jam with water, and DJ: desamerized jam. Values with the same letter in each column show no significant difference $(p>0.05)$. Results are ranked in descending order: $a>b>c>d>e>f>g$.

\subsubsection{Sensory Analysis}

(1) Grading Test. The subject's task (30 trained subjects) consists in presenting him with a series of coded jams and asking him to classify them in order of intensity of bitterness. The samples are presented simultaneously in increasing (or decreasing) intensity of the analyzed characteristics [25].

(2) Hedonic Test. Hedonic tests are designed to measure the degree of appreciation of a product. We use categories ranging from "likes a lot" to "do not like at all" through "neutral" with a variable number of intermediate categories. For each sample, the tasters select the category corresponding to their degree of appreciation. Compared to the classification test, it has the advantage of not requiring the simultaneous evaluation of all the products studied, but it supposes a good sensory memory of the scale of notation. Codified products are presented to a panel of 30 subjects. Each subject receives the samples in cups coded with three digits. The order of presentation of samples is random [25].

2.2.6. Statistic Study. The statistical analysis is carried out using the software Statistica 5.5. Analysis of variance was performed by ANOVA procedure with one factor for the physicochemical and antioxidant results. For the results of the sensory analysis, we applied the test of multiple comparisons in pairs of the sums of the rows. For the results of the hedonic analysis, the categories are converted into numerical notations ranging from 1 to 9 , where 1 corresponds to "does not like at all" and 9 "loves a lot." The scores for each sample are presented in tabular form and analyzed by means of the variance analysis.

\section{Results and Discussions}

No data were available on the physicochemical parameters and the desamerisation of Bigarade jam, which makes comparison very difficult. So, all of the comparisons were made with results obtained on jam made from other fruits.

3.1. Physicochemical Analyzes. The physicochemical characteristics of the jams and parts of the fruit analyzed are illustrated in Table 1.
3.1.1. Hydrogen Potential ( $p H) . \mathrm{pH}$ is a parameter determining the suitability of food for conservation, and it is one of the main obstacles that microbial flora must overcome to ensure its proliferation. Thus, a pH of the order of 3 to 6 is very favorable to the development of yeasts and molds [26].

According to the results presented in Table 1, the $\mathrm{pH}$ varies significantly $(p \leq 0.05)$ according to the parts of the fruit. The $\mathrm{pH}$ of the edible portion of the fruit is 2.51 , which classifies the fruit as an acid fruit. Karadeniz [27] reported a $\mathrm{pH}$ value of Bigarade juice similar to ours (2.52).

The $\mathrm{pH}$ differs significantly $(p \leq 0.05)$ between the bitter jam and the desamerized jams. The $\mathrm{pH}$ of jams varied from 2.80 to 2.87 . These results are consistent with those required by the Codex Alimentarius $(\mathrm{pH}<3.5)$. The $\mathrm{pH}$ of jam is an important factor to obtain an optimum gel condition [28]. Control of $\mathrm{pH}$ is critical to successful gel formation with pectins, particularly high methoxyl pectins. Low $\mathrm{pH}$ increases the percentage of unionized carboxyl groups, thus reducing electrostatic repulsion between adjacent pectin chains [29]. Our results are slightly higher than those found by Ellouze et al. [30] who worked on bitter orange marmalade. The latter yielded $\mathrm{pH}$ values between 2.3 and 2.6 .

3.1.2. Titratable Acidity. The titratable acidity tells us the amount of organic acids present in the sample. Organic acids are, in general, intermediates of metabolic processes; they influence the growth of microorganisms and affect the quality of preservation of the products. They are directly involved in the growth, maturation, and senescence of the fruit. These acids also influence the sensory properties of fruits [31].

According to our results, the titratable acidity varies significantly $(p \leq 0.05)$ depending on the parts of the fruit. The acidity of peels and edible part is $20.91 \mathrm{~g} / \mathrm{l}$ and $48.00 \mathrm{~g} / \mathrm{l}$, respectively (Table 1 ). The results found for the edible portion are similar to those found by Ellouze et al. [30] $(49.92 \mathrm{~g} / \mathrm{l})$ in Bigarade juice.

The bitter jam is considered to be significantly ( $p \leq 0.05)$ the most acidic $(27.84 \mathrm{~g} / \mathrm{l})$. The acidity of the desamerized jams varies from $24.33 \mathrm{~g} / \mathrm{l}$ to $24.96 \mathrm{~g} / \mathrm{l}$. The acidity is usually provided by the fruit which contains citric acid, tartaric acid, etc. [32].

3.1.3. Rate of Soluble Solids (Brix). From our results (Table 1), it is noted that the soluble solid contents of the peels is statistically similar $(p>0.05)$ to that of the edible portion. 
The Brix level of the peels $(11.67 \pm 0.58)$ is slightly lower than the rate found by Moufida and Marzouk [33]. These authors have recorded a value of $12.24 \%$ for bitter orange. This difference in outcome can be explained by the influence of a few parameters such as climate, soil type, and fruit maturation process [9].

The Brix level of our jams is in the range of 59.67 to $65.33 \%$. Sugar brings consistency and mass to the product and also promotes gelling [34].

3.1.4. Moisture Content. According to the results presented in Table 1 , the moisture varies significantly $(p \leq 0.05)$ from one jam to another depending on the parts of the fruit. The average moisture content of the fruit (peels and edible portion) is $78.34 \%$. The moisture is highest in the edible part $(89.69 \%)$ compared to that registered in peels $(67 \%)$. These results are lower than those found by Lagha-Benamrouche and Madani [35]. The latter recorded a content of $75.82 \%$ for the peels and a value of $94.91 \%$ for the pulp. This variation in water content may also be due to different environmental conditions: exposure to different pedoclimatic conditions and geographical distribution [36].

By comparing the moisture content of our jams (33.82 to 39.54\%) with those found by Mohd Naeem et al. [37] for fruit jams (strawberry, apricot, and blueberry (31.23 to $33.36 \%)$ ) and Aina et al. [38] for pineapple jam (30\%), we find that our jams are the moistest. Generally, the moisture content of foods can be used as an indicator of its shelf life. Low moisture content indicates that the jams have a long shelf life [39].

3.2. Chemical Composition of Jams and Fruit Parts. The chemical composition of the jams and the fruit parts studied are shown in Table 2. The spider diagram (Figure 1) allows better visualization of the effect of desamerization on the chemical composition of jams.

3.2.1. Ashes. From the obtained results (Table 2), we can observe that the ash content varies significantly $(p \leq 0.05)$ according to the analyzed samples. The mineral content of the peels $(0.67 \%)$ is higher compared to that registered in the edible part $(0.33 \%)$. The data analysis shows that also the ash content of the peels is higher than the result reported by Aissou [40] for orange peel, lemon, and grapefruit. The latter are of the order of $0.30 \%, 0.32 \%$, and $0.26 \%$, respectively. The variation in the ash content of the fruit can be explained by the geographical origin, the climatic conditions, and the edaphic characteristics of the soils [41].

Concerning jams (Table 2), the ash content of the bitter jam is higher than the result reported by Aina et al. [38] for pineapple jam and Mohd Naeem et al. [37] for apricot jam. The latter are of the order of $0.05 \%$ and $0.25 \%$, respectively. Minerals are essential for the proper functioning of tissues and act as second messengers in some biochemical cascade mechanisms [42]: average catalysts, mediate cell responses, control growth, and cell differentiation [43].

The results show that also the ash content proportionally increases with salt concentration in jams. This increase is due to the dissolution of $\mathrm{NaCl}$ in the medium giving $\mathrm{Na}^{+}$and $\mathrm{Cl}^{-}$, which are mineral salts.

3.2.2. Pectins. Pectin is a polysaccharide present in plant cell walls, especially in fruits. Pectin is a component of soluble fiber with interesting technological applications in the gelling of a mixture of fruit and vegetable sugar.

According to our results, the peels are richer in pectin than the edible part $(0.74 \%$ versus $0.11 \%$, resp.) (Table 2$)$. Comparing our results with those obtained by Sulieman et al. [44], for sweet oranges, it is found that our present fruit has much lower pectin contents ( 1 to $3.5 \%$ versus 0.1 to $0.74 \%$, resp.). According to Kansci et al. [45], this difference may be due to the cultivation conditions and degree of ripeness of the fruit but also to the dosage method used. Technically, the low pectin content is an advantage in the production of clarified juices and syrups (clarification process) but a disadvantage for the preparation of jellies, jams, and marmalades.

The results obtained for the jams (Table 2 ) show that there are no significant differences $(p>0.05)$ in the pectin contents of desamerized jams and bitter jam; the desamerization does not seem to affect the pectin content of the jams.

3.2.3. Proteins. The results shown in Table 2 reveal that the Bigarade peels are richer in protein than the edible portion. The contents vary significantly $(p \leq 0.05)$ from 1.679 to $0.076 \mathrm{~g} / 100 \mathrm{~g}$ FM, respectively. The protein content of Bigarde peels (=1.7 g/100 g FM.) was comparable to the one reported for Thomson peels (1.8 g/100 g FM.) [46].

The protein content in the jams vary from $0.485 \mathrm{~g} / 100 \mathrm{~g}$ FM to $0.98 \mathrm{~g} / 100 \mathrm{~g} \mathrm{FM}$, comparing our results with those obtained by Mohd Naeem et al. [37] and Eke-Ejiofor and Owuno [47] for apricot ( $0.43 \mathrm{~g} / 100 \mathrm{~g}$ FM.) and pineapple jams (0.46 g/100 g FM.), respectively. According to the jams' nutrition labelling, common ingredients are fruits, sugar, pectin, and citric acid. None of the ingredients used are an abundant source of protein; hence, this richness of protein is explained by the richness of our fruit, peels, in this compound. Bitter jam is the richest in protein followed by DJW. The results also show that desamerization decreases the protein content of the jams. Proteins are more soluble in solutions of ionic salts than in distilled water. At higher salt concentrations, protein solubility usually decreases, leading to precipitation; this effect is termed salting-out. Salts that reduce the solubility of proteins also tend to enhance the stability of the native conformation. In contrast, salting-in ions are usually denaturants [48].

3.2.4. Total Sugars. The results shown in Table 2 reveal that the total sugar contents of the peels and the edible part are in the range from 10.77 to $10.03 \mathrm{~g} \mathrm{GE} / 100 \mathrm{~g}$ FM, respectively. Our results show that our fruit contains total sugar content close to those found by Ellouze et al. [30]. The latter yields between 9.61 and $11.40 \mathrm{~g} / 100 \mathrm{~g}$ FM.

This variation can be attributed to several factors such as plant age, maturation stage, and fruit physiological state during the analysis [49]. 


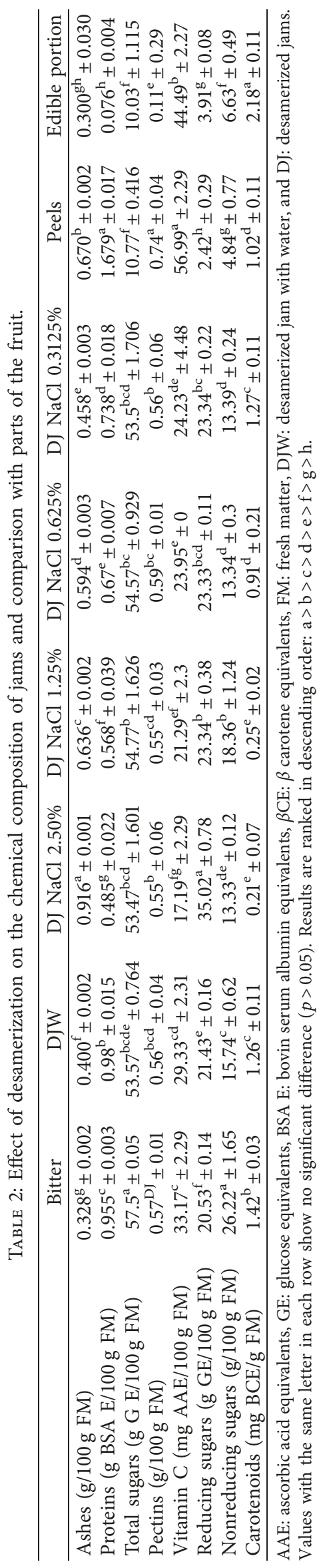


For the jams, the results show that the total sugar levels differ significantly $(p \leq 0.05)$ between the bitter jam and the desamerized jams. This can be explained by the phenomenon of diffusion of the matter (osmosis) and the training of the sugars with the washing waters of the mesocarpe during the desamerization.

The total sugar content of our jams $(57.5-53.47 \mathrm{~g}$ GE/100 g FM) is lower than the bibliographic data. Aissou [40] recorded a rate of $68 \mathrm{~g} / 100 \mathrm{~g}$ FM for a jam based on orange, lemon, and grapefruit pulp. The noticeable differences could be caused by the addition of sugar during the jam-making process [50]. According to Oakenfull [34], the sugar attracts water molecules, which concentrates the pectin molecules and promotes gelling. The addition of sugar is essential in order to preserve the jams satisfactorily. In comparison with apricot jam, Touati et al. [51] reported total sugars to be higher $(64.88 \mathrm{~g} / 100 \mathrm{~g})$ than in the investigated jam. This difference may be related to the low soluble solid content of our fruit.

3.2.5. Reducing Sugars. The results shown in Table 2 indicate that the reducing sugar contents of the edible portion (3.91 \pm $0.08 \mathrm{~g} / 100 \mathrm{~g} \mathrm{FM})$ and the peels $(2.42 \pm 0.29 \mathrm{~g} / 100 \mathrm{~g} \mathrm{FM})$ are included in the interval given by Aissou [40] for sweet oranges (2.25-3.83 g/100 g FM). According to Ayaz [52], the variation in the levels of reducing sugars can be attributed to various factors including the maturation stage, temperature, duration of exposure to the sun, and climatic conditions and also to genetic factors.

Reduced sugars varied significantly $(p \leq 0.05)$ between jams with exception for DJ $\mathrm{NaCl} 0.3125 \%$, DJ $\mathrm{NaCl} 1.25 \%$, and $\mathrm{DJ} \mathrm{NaCl} 0.625 \%$. It is the bitter jam which is the poorest in reducing sugars $(20.53 \mathrm{~g} / 100 \mathrm{~g} \mathrm{FM})$, followed by DJW $(21.43 \mathrm{~g} / 100 \mathrm{~g}$ FM). The highest content was found for DJ $\mathrm{NaCl} 2.5 \%$ ( $35 \mathrm{~g} / 100 \mathrm{~g}$ FM). This can be explained by the hydrolysis of sucrose contained in the jam during cooking. The acidity associated with a high temperature causes the inversion of $30-50 \%$ of added sucrose. The inversion of sucrose has its consequences:

(i) Increased sweetness: fructose is sweeter than sucrose (sweetening power $=1.14$ ).

(ii) Obtaining a solution containing more dry matter: fructose and glucose which are more soluble than sucrose [53].

3.2.6. Nonreducing Sugars. Comparison of the nonreducing sugar content of the edible part of the fruit with that of the peels shows the richness of the edible part of these compounds. Values ranged from 6.63 to $4.84 \mathrm{~g} / 100 \mathrm{~g} \mathrm{FM}$, respectively.

The nonreducing sugar content of the jams varied significantly $(p \leq 0.05)$ between the jams except for DJ $\mathrm{NaCl}$ $0.625 \%$, DJ NaCl $2.5 \%$, and DJ NaCl $0.3125 \%$. The contents range from $13.33 \%$ to $26.22 \%$. Bitter jam contains more nonreducing sugars; the lowest content is found in the DJ $\mathrm{NaCl} 2.5 \%$, DJ $\mathrm{NaCl} 0.625 \%$, and $\mathrm{DJ} \mathrm{NaCl} 0.3125 \%$. This can be explained by the effect of cooking and salt used for

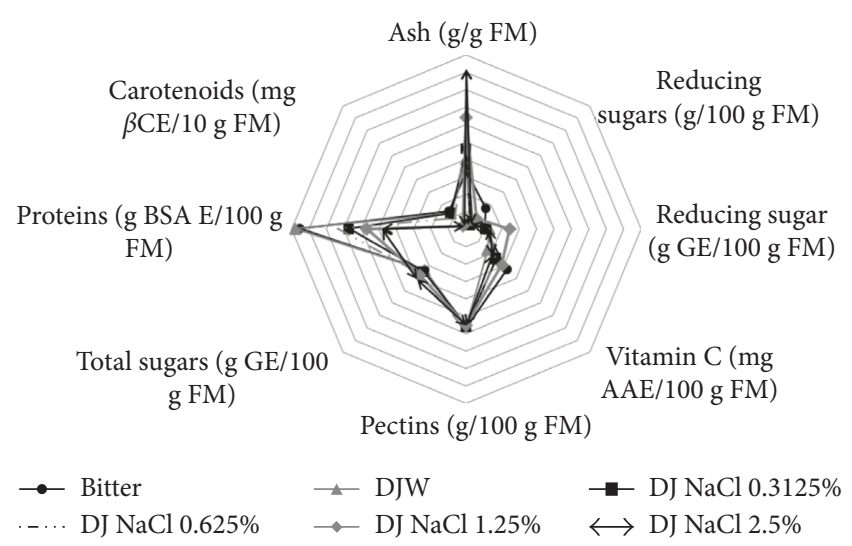

Figure 1: Comparison of effect of desamerization on the chemical composition of jams. AAE: ascorbic acid equivalents, GE: glucose equivalents, BSA $\mathrm{E}$ : bovin serum albumin equivalents, $\beta \mathrm{CE}$ $\beta$ carotene equivalents, AAE: ascorbic acid equivalents, FM: fresh matter, DJW: desamerized jam with water, and DJ: desamerized jams.

desamerization. The presence of salt causes training of the sucrose with the washing waters of the mesocarpe during the desamerization. Cooking reduces sucrose content (which is a nonreducing sugar) following its hydrolysis into glucose and fructose.

3.2.7. Vitamin $C$. The results of the determination of vitamin $\mathrm{C}$ in different parts of the fruit show that peels contain more vitamin $\mathrm{C}$ compared to the edible part. The contents range from 56.99 to $44.49 \mathrm{mg} / 100 \mathrm{~g}$ FM, respectively. Our result corroborates those of Gorinstein et al. [54]. These authors have reported that citrus peels appear to contain more vitamin $\mathrm{C}$ than the edible part (pulp). It contains only $0.477 \mathrm{mg} / \mathrm{g}$ FM for orange, $0.479 \mathrm{mg} / \mathrm{g}$ FM for lemon, and $0.351 \mathrm{mg} / \mathrm{g} \mathrm{FM}$ for grapefruit, compared to $0.596,0.598$, and $0.438 \mathrm{mg} / \mathrm{g} \mathrm{FM}$ for the peels of the same varieties of citrus, respectively. These results also show that orange peel is the richest in ascorbic acid. The variability of the ascorbic acid content of fruits is influenced by the seasonal and annual variations in the degree of sunshine and humidity, the variety of the fruit, the position of the fruits on the tree, and their degrees of ripeness [55]. Other factors may also be involved, such as the sensitivity of ascorbic acid to oxidation by air and in an aqueous medium. Quantification is also influenced by the assay method, which is itself dependent on the complexity of the plant material [56].

For jams, the results show that the vitamin $C$ levels decrease significantly $(p \leq 0.05)$ with desamerization. The levels pass from $33.17 \mathrm{mg} / 100 \mathrm{~g}$ FM for bitter jam to $17.19 \mathrm{mg} / 100 \mathrm{~g}$ $\mathrm{FM}$ for $\mathrm{DJ} \mathrm{NaCl} 2.5 \%$. This tremendous decrease in vitamin C content in jam is due to the use of heat treatment in the desamerization processing and probably is mainly due to oxidation of vitamin C. The oxidation of vitamin $\mathrm{C}$ may also be due to the elimination of some bitter flavonoids. According to Dupaigne [57], degradation of naringine during desamerization is accompanied by loss of vitamin $\mathrm{C}$.

The analyzed jams have vitamin $\mathrm{C}$ contents between 17.19 and $33.17 \mathrm{mg} / 100 \mathrm{~g}$ FM. The vitamin C content of our 
TABLE 3: Effect of desamerization on the phenolic composition of jams and comparison with parts of the fruit.

\begin{tabular}{|c|c|c|c|c|c|c|c|c|}
\hline & Bitter & DJW & $\begin{array}{c}\text { DJ } \mathrm{NaCl} \\
2.50 \% \\
\end{array}$ & $\begin{array}{c}\text { DJ } \mathrm{NaCl} \\
1.25 \% \\
\end{array}$ & $\begin{array}{c}\text { DJ } \\
0.6\end{array}$ & $\begin{array}{l}\text { DJ } \\
0.3\end{array}$ & Peels & $\begin{array}{l}\text { Edi } \\
\text { port }\end{array}$ \\
\hline $\begin{array}{l}\text { lol } \\
\text { g FM) }\end{array}$ & & & & & & & & \\
\hline $\begin{array}{l}\text { Flavonoids } \\
\text { (mg QE/g FM) }\end{array}$ & & $6.29^{b c} \pm 0.10$ & $4.83^{\mathrm{ef}} \pm 0.77$ & & $6.10^{\mathrm{d}} \pm 0.01$ & $6.24^{\mathrm{bc}} \pm 0.12$ & & $10.8^{\mathrm{a}} \pm 0.04$ \\
\hline $\begin{array}{l}\text { Flavonols } \\
\text { (mg QE/g FM) }\end{array}$ & & $1.49^{b c} \pm 0.12$ & $0.56^{\mathrm{fg}} \pm 0.17$ & $0.76^{\mathrm{f}} \pm 0.06$ & $1.14^{\mathrm{e}} \pm 0.17$ & $1.23^{\mathrm{cd}} \pm 0.06$ & $0.29^{\mathrm{h}} \pm 0.02$ & $1.59^{\mathrm{ab}} \pm 0.11$ \\
\hline $\begin{array}{l}\text { Proanthocyanidins } \\
(\mu \mathrm{g} \text { CE/g FM })\end{array}$ & $40.91^{\mathrm{b}} \pm 0.30$ & $40.53^{\mathrm{c}} \pm 0.05$ & $36.36^{\mathrm{g}} \pm 0.15$ & $38.24^{\mathrm{ef}} \pm 0.14$ & $38.42^{\mathrm{e}} \pm 0.25$ & $40.47^{\mathrm{cd}} \pm 0.09$ & $0.07^{\mathrm{h}} \pm 0.00$ & $51.05^{\mathrm{a}} \pm 0.29$ \\
\hline
\end{tabular}

GAE: gallic acid equivalents, CE: catechin equivalents, QE: qercetin equivalents, FM: fresh matter, DJW: desamerized jam with water, and DJ: desamerized jams. Values with the same letter in each row show no significant difference $(p>0.05)$. Results are ranked in descending order: $a>b>c>d>e>f>g>h$.

jams is much higher than the results obtained by Tanwar et al. [58]. The authors have reported vitamin C levels of around $7.5 \mathrm{mg} / 100 \mathrm{~g}$ for the guava jam. We found that our jams are very rich in vitamin C. This richness of ascorbic acid is explained by the richness of our fruit, peels, in vitamin C [35]. The latter refers levels of vitamin $C$ in the range of $9.12 \mathrm{mg} \mathrm{AAE} / \mathrm{g}$ FM.

3.2.8. Carotenoids. According to our results, the peels are richer in carotenoids than the edible part $(2.18 \mathrm{mg} \beta \mathrm{CE} / \mathrm{g}$ $\mathrm{FM}$, versus $1.02 \mathrm{mg} \beta \mathrm{CE} / \mathrm{g} \mathrm{FM}$, resp.). Our results corroborate those of Wang et al. [59]. These authors have reported that orange peels are richer in carotenoids than the edible part of the fruit $(445 \mu \mathrm{g} \mathrm{E} \beta \mathrm{c} / \mathrm{g}$ FM for peels versus $5.17 \mu \mathrm{g}$ $\mathrm{E} \beta \mathrm{c} / \mathrm{g} \mathrm{FM}$ for the edible part).

The results obtained for jams (Table 2) show that the carotenoid content varies significantly $(p \leq 0.05)$ between jams except for (DJ NaCl 1.25\%-DJ $\mathrm{NaCl} 2.5 \%$ ) and (DJ $0.3125 \% \mathrm{NaCl}-\mathrm{DJW})$. On the basis of carotenoid content, jams are classified in descending order: bitter jam $(1.42 \mathrm{mg}$

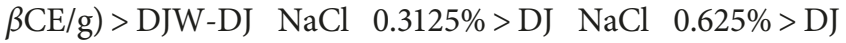
$\mathrm{NaCl} 1.25 \%-\mathrm{DJ} \mathrm{NaCl} 2.5 \%(0.21 \mathrm{mg} \beta \mathrm{CE} / \mathrm{g})$. The results also show that bitter jam contains fewer carotenoids than fresh fruit. Since there are double bonds in the carbon chain, carotenoids are susceptible to some reactions such as oxidation and isomerisation (cis-trans) during food processing and storage, especially due to light, heat, acids, and oxygen, thus causing loss of color and reduction of biological activity [60].

3.2.9. Phenolic Contents of Sample. The results of the determination of phenolic content in different parts of the fruit show that the peels contain more total polyphenols, flavonoids, flavonols, and proanthocyanidins compared to the edible part Table 3. The total polyphenol content of the peels is four times higher than that of the edible part (31.96 mg GAE/g FM versus $7.45 \mathrm{mg} \mathrm{GAE} / \mathrm{g} \mathrm{FM}$ ), while the flavonoid and flavonol contents are approximately six times higher $(10.8 \mathrm{mg}$ $\mathrm{EQ} / \mathrm{g} \mathrm{FM}$ versus $1.68 \mathrm{mg} \mathrm{EQ} / \mathrm{g} \mathrm{FM}$ and $1.59 \mathrm{mg} \mathrm{EQ/g} \mathrm{FM}$ versus $0.29 \mathrm{mg} \mathrm{EQ} / \mathrm{g} \mathrm{FM}$, resp.). The results also show that the proanthocyanidin contents of the edible part is negligible compared with that of the peels $(0.07 \mathrm{mg}$ EC/g FM versus $\mathrm{mg}$ EC/g FM). Our results corroborate those of Guimarães et al. [61]. These authors have reported that citrus peels appear to contain more phenolic content than the edible part.
For jams, the results show that the phenolic levels decrease significantly $(p \leq 0.05)$ with desamerisation. The levels pass from $33.61 \mathrm{mg} \mathrm{GAE} / \mathrm{g}$ for bitter jam to $18.18 \mathrm{mg} \mathrm{GAE} / \mathrm{g}$ for DJ $\mathrm{NaCl} 2.5 \%$ concerning total phenol, from $6.39 \mathrm{mg} \mathrm{QE} / \mathrm{g}$ to $4.83 \mathrm{mg} \mathrm{QE} / \mathrm{g}$ for flavonoides, from $1.75 \mathrm{mg} \mathrm{QE} / \mathrm{g}$ to $0.56 \mathrm{mg}$ $\mathrm{QE} / \mathrm{g}$ for flavonols, and from $40.91 \mathrm{mg} \mathrm{CE} / \mathrm{g}$ to $36.36 \mathrm{mg} \mathrm{CE} / \mathrm{g}$, respectively. On the basis of the content of phenolic compounds, jams are classified in descending order: bitter jam > DJW-DJ $\mathrm{NaCl} 0.3125 \%$ > DJ NaCl $0.625 \%$ > DJ NaCl $1.25 \%$-DJ $\mathrm{NaCl} 2.5 \%$. The results show that the phenolic compound levels significantly decrease $(p \leq 0.05)$ with desamerisation. This decrease can be explained by the effect of cooking and salt used for desamerization. The presence of salt causes training of the phenolic compounds, which are water soluble, with the washing waters of the mesocarpe during the desamerization. Other factors may also be involved, such as the sensitivity of phenolic compounds to oxidation by air and temperature and in an aqueous medium. Klopotek et al. [62] show that treating strawberry at $80^{\circ} \mathrm{C}$ for 15 minutes causes a $30 \%$ loss of phenolic compounds. Water is a source of degradation of phenolic compounds; in the presence of water, an enzymatic activity may quickly cause irreversible changes in antioxidants, such as oxidation which leads to their decomposition or polymerization [63]. The comparison of our results with historical data shows that Bigarade jam is very rich in total polyphenols and flavonoids compared to strawberry jam. According to Plessi et al. [64] and Danijela et al. [65], the contents of these compounds are $310-510 \mathrm{mg}$ $\mathrm{GAE} / 100 \mathrm{~g}$ and $0.7-0.75 \mathrm{mg} / 100 \mathrm{~g}$, respectively.

3.3. Antioxidant Activity. The antioxidant potential of jams was estimated using the method of reduction of potassium ferricyanide. The presence of reducing agents in the extracts induced reduction of the ferric ions $\left(\mathrm{Fe}^{+3}\right)$ to ferrous ion $\left(\mathrm{Fe}^{+2}\right)$. This reduction is measured by the intensity of the blue-green color that results. It absorbs at a wavelength of $700 \mathrm{~nm}$. An increase in absorbance indicates a high reducing power.

The analysis of the reducing power of jams at the concentration of $1 \mathrm{mg} / \mathrm{ml}$ resulted in absorbances between 0.805 and 0.556 (Figure 2). As can be seen, it is the bitter jam that has the highest absorbances and therefore the most pronounced reductive power. On the basis of the reducing capacity, the jams are classified in descending order as following: bitter jam > DJW-DJ $\mathrm{NaCl} 0.3125 \%>\mathrm{DJ} \mathrm{NaCl} 0.625 \%>\mathrm{DJ} \mathrm{NaCl}$ 


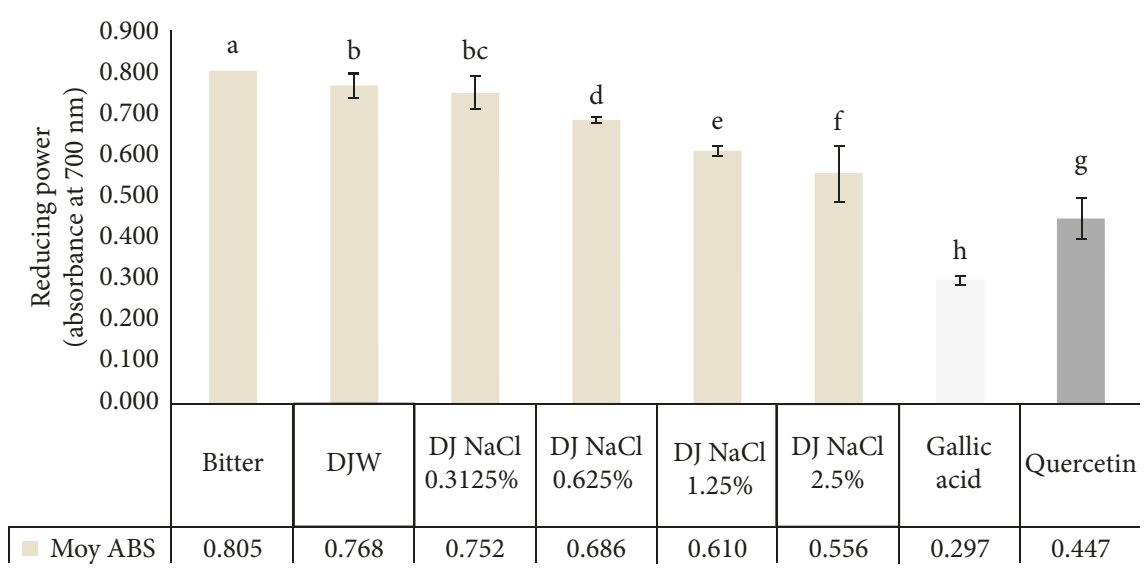

FIGURE 2: Reducing power of jams at $1 \mathrm{mg} / \mathrm{ml}$, quercetin and gallic acid at $0.02 \mathrm{mg} / \mathrm{ml}$. FM: fresh matter, DJW: desamerized jam with water, and DJ: desamerized jams.Values bearing the same letter showed no significant difference $(p \leq 0.05)$. The results are sorted in decreasing order: $a>b>c>d>e>f>g>h$.

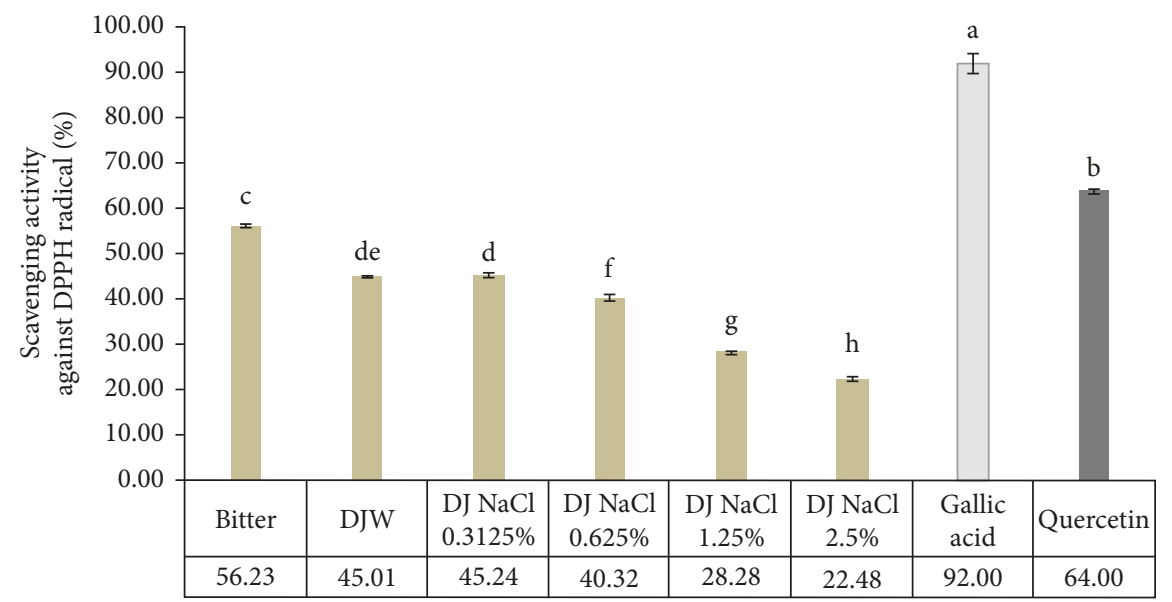

FIGURE 3: Mean antioxidant activity against DPPH radical of jams at $1 \mathrm{mg} / \mathrm{ml}$ and standards at $40 \mu \mathrm{g} / \mathrm{ml}$. DJW: desamerized jam with water, DJ: desamerized jams, and DPPH: 1,1-diphenyl 1-2-picrylhydrazyl. Values bearing the same letter showed no significant difference $(p \leq 0.05)$. The results are sorted in decreasing order: $a>b>c>d>e>f>g>h$.

$1.25 \%>\mathrm{DJ} \mathrm{NaCl} 2.5 \%$. These results also show that the reducing power of jams is significantly higher $(p \leq 0.05)$ than that of standards tested at $0.02 \mathrm{mg} / \mathrm{ml}$ : quercetin and gallic acid (respective absorbances: 0447 and 0.29).

The scavenging model of DPPH radical is widely used as a method for assessing antioxidant activity in a period relatively short compared to other methods. As displayed in Figure 3, the antiradical activity values for investigated extracts (at a concentration of $1 \mathrm{mg} / \mathrm{ml}$ ) varied between $56.23 \%$ and $22.48 \%$. The bitter jam presents the highest antiradical activity. The latter is significantly lower $(p \leq 0.05)$ than that of the standards tested. Based on the antiradical activity, the jams are classified in the following order: bitter jam> DJW-DJ NaCl 0.3125\% > DJ NaCl $0.625 \%>\mathrm{DJ} \mathrm{NaCl} 1.25 \%>\mathrm{DJ} \mathrm{NaCl} 2.5 \%$. These results show that the antioxidant potential is inversely proportional to the salt concentration used for the desamerisation. This can be explained by the loss of compounds with antioxidant potential as already observed during their quantification.

Comparing our results with the bibliographic data leads us to say that Bigarade jam exhibits a higher antioxidant activity than melon jam which was $4.95 \%$ according to Benmeziane et al. [63] and than cherry, apricot, and fig jam (10.06\%, 9.95\%, and $8.96 \%$, resp.), according to Rababah et al. [66].

The coefficients of correlation between the antioxidant capacities of jams and the contents of bioactive compounds are illustrated in Table 4. Significant positive correlations $(p \leq 0.05)$ were observed between the contents of bioactive compounds (polyphenols, flavonoids, flavonols, and carotenoids) and the antioxidant capacities evaluated by the methods of reducing power and inhibition of the radical DPPH $(R 2=0.753-0.981)$. Similar results have been observed by Lagha-Benamrouche and Madani [35]. However, low correlation coefficients were observed between vitamin $\mathrm{C}$ and proanthocyanidin levels and antioxidant activities $(R 2=0.025-0.437)$.

\subsection{Results of Sensory Evaluation}

3.4.1. Rankings by Degree of Bitterness. To process the data from the ranking tests in a first step, we calculated all the differences between the sums of the ranks of the products 
TABLE 4: Correlation matrix between the levels of bioactive compounds and the antioxidant activities of jams.

\begin{tabular}{|c|c|c|c|c|c|c|c|c|}
\hline & $\mathrm{TP}$ & $\mathrm{F}$ & FOL & PAC & $\mathrm{VC}$ & Car & $\mathrm{RP}$ & DPPH \\
\hline $\mathrm{TP}$ & 1 & - & - & - & - & - & - & - \\
\hline F & $0.870^{*}$ & 1 & - & - & - & - & - & - \\
\hline FOL & $0.829^{*}$ & $0.690^{*}$ & 1 & - & - & - & - & - \\
\hline PAC & 0.519 & $0.816^{*}$ & 0.297 & 1 & - & - & - & - \\
\hline VC & 0.033 & 0.003 & 0.045 & $0.657^{*}$ & 1 & - & - & - \\
\hline Car & $0.956^{*}$ & $0.800^{*}$ & $0.898^{*}$ & 0.476 & 0.003 & 1 & - & - \\
\hline $\mathrm{RR}$ & $0.981^{*}$ & $0.804^{*}$ & $0.954^{*}$ & 0.437 & 0.025 & $0.963^{*}$ & 1 & - \\
\hline DPPH & $0.948^{*}$ & $0.753^{*}$ & $0.961^{*}$ & 0.341 & 0.086 & $0.931^{*}$ & $0.963^{*}$ & 1 \\
\hline
\end{tabular}

TP: total polyphenol, F: flavonoids, FOL: flavonol, PAC: proanthocyanidins, VC: vitamin C, Car: carotenoids, RP: reducing power, and DPPH: 1.1-diphenyl 1-2-picrylhydrazyl. *Significant correlation $(p<0.05)$.

TABle 5: Multiple comparisons by pair of the sums of rows for the degree of bitterness of the jams.

\begin{tabular}{|c|c|c|c|c|c|}
\hline Samples & Effective $(n)$ & Sums of ranks & $\begin{array}{l}\text { Differences in the ranks } \\
\text { between the possible pairs }\end{array}$ & $\begin{array}{c}\text { Critical value for } p \leq 0.05 \text { and } \\
\text { effective }=30 \text { number of products }=6\end{array}$ & Groups \\
\hline Bitter (1) & 30 & 30 & $\begin{array}{l}(2)-(1)=33 \\
(3)-(1)=86^{*} \\
(4)-(1)=78^{*} \\
(5)-(1)=107^{*} \\
(6)-(1)=149^{*}\end{array}$ & 42 & A \\
\hline DJW (2) & 30 & 63 & $\begin{array}{l}(3)-(2)=53^{*} \\
(4)-(2)=45^{*} \\
(5)-(2)=74^{*} \\
(6)-(2)=116^{*}\end{array}$ & 42 & A \\
\hline DJ $\mathrm{NaCl} 0.312 \%$ (3) & 30 & 116 & $\begin{array}{c}(3)-(4)=08 \\
(5)-(3)=21 \\
(6)-(3)=63^{*}\end{array}$ & 42 & B \\
\hline DJ $\mathrm{NaCl} 0.625 \%(4)$ & 30 & 108 & $\begin{array}{c}(5)-(4)=29 \\
(6)-(4)=61^{*}\end{array}$ & 42 & $\mathrm{~B}$ \\
\hline DJ $\mathrm{NaCl} 1.25 \%(5)$ & 30 & 137 & $(6)-(5)=42^{*}$ & 42 & $\mathrm{~B}$ \\
\hline DJ $\mathrm{NaCl} 2.5 \%(6)$ & 30 & 179 & - & - & $\mathrm{C}$ \\
\hline
\end{tabular}

DJW: desamerized jam with water; DJ: desamerized jam. * Significant at the $p \leq 0.05$ level.

taken 2 to 2 . Then, in a second step, we read the critical value at the intersection of the column (products) and line (subjects) on the table of Newell and MacFarlane corresponding to the risk $\alpha \leq 5 \%$. Any calculated difference between the products, equal to or greater than this critical value, means that the corresponding products can be regarded as different (Table 5).

The calculated value for bitter jam and desamerized jam with water is less than the critical value. We conclude, therefore, that there is no discernible difference between the two jams, and the latter are classified in the same group (A) and possess the same degree of bitterness.

The multiple paired comparisons of the three desamerified jams with $\mathrm{NaCl}$ at the following percentages $0.3125 \%, 0.625 \%$, and $1.25 \%$ showed no significant difference in the degree of desamerization between them; the tasters find that these jams are less bitter than the previous ones but do not differ between them, and they are therefore classified in another group (B). The calculated value for desamerified jams with $\mathrm{NaCl}$ at the percentages $1.25 \%$ and $2.5 \%$ is equal to the critical value. It is concluded that the difference in perceived bitterness between the two samples is significant, and the two jams are classified into two different groups.
3.4.2. Hedonic Test. After the evaluation of the five samples, the descriptive categories were converted into numerical notations. The results are tabulated and analyzed for variance (Table 6).

The coefficients $F$ for treatment and tasters were calculated by dividing the respective AS (average square) values by the AS of the error. The calculated $F$ coefficients must exceed the $F$ coefficients in the $F$ distribution table (significance at $p \leq 5 \%)$.

As the coefficient $F$ calculated for the treatment ( $F$ 25.13) exceeded the coefficient of the table ( $F 2.6)$, it was concluded that there is a significant difference $(p \leq 0.05)$ between the averages of the hedonic results for the five desamerized jams. The results indicate that also the calculated coefficient for the tasters ( $F$ 3.95) exceeds the coefficient of the table (F 2.07). Such results reveal, therefore, a significant effect attributable to the tasters.

Analysis of variance indicated that there were significant differences between the five desamerized jams. In order to determine which samples of jam differ significantly from each other, a multiple comparison test was conducted; Duncan's new multiple comparison test was conducted using the critical value tables ( $Q$ values) at a significance level of $5 \%$. This test compares the differences between all pairs of 
TABLE 6: Results by category of the hedonic test.

\begin{tabular}{|c|c|c|c|c|c|c|c|}
\hline \multicolumn{8}{|c|}{ Desamerized jams (processing) } \\
\hline Tasters & DJW & DJ $\mathrm{NaCl} 2.5 \%$ & DJ $\mathrm{NaCl} 1.25 \%$ & DJ $\mathrm{NaCl} 0.625 \%$ & DJ $\mathrm{NaCl} 0.3125 \%$ & Total tasters & Average tasters \\
\hline 1 & 1 & 1 & - & - & 1 & 3 & 0.6 \\
\hline 2 & 6 & - & 4 & - & 6 & 16 & 3.2 \\
\hline 3 & - & 1 & 7 & - & - & 8 & 1.6 \\
\hline 4 & - & 6 & - & - & 7 & 13 & 2.6 \\
\hline 6 & - & - & - & 7 & - & 7 & 1.4 \\
\hline 8 & 4 & - & - & - & - & 4 & 0.8 \\
\hline 9 & 3 & 3 & 5 & 9 & 9 & 29 & 5.8 \\
\hline 10 & 2 & - & - & - & - & 2 & 0.4 \\
\hline 13 & - & 4 & - & - & - & 4 & 0.8 \\
\hline 14 & - & - & - & - & 8 & 8 & 1.6 \\
\hline 15 & - & - & - & 8 & - & 8 & 1.6 \\
\hline 16 & - & - & 6 & - & - & 6 & 1.2 \\
\hline Total treatment & 16 & 15 & 22 & 24 & 31 & & \\
\hline Grand total & & & & & & 108 & \\
\hline Average treatment & 3.2 & 5 & 5.5 & 8 & 6.2 & & \\
\hline
\end{tabular}

Highest score $=9$ (likes enormously), lowest score $=1$ (disliked). DJ: desamerized jam. DJW: desamerized jam with water; DJ: desamerized jam.

TABLE 7

\begin{tabular}{lccccc}
\hline Desamerized jams & DJW & DJ NaCl $2.5 \%$ & DJ NaCl $1.25 \%$ & DJ NaCl $0.3125 \%$ & DJ NaCl $0.625 \%$ \\
\hline Average treatment & 3.2 & 5 & 5.5 & 6.2 & 8 \\
\hline
\end{tabular}

TABLE 8: Paired comparisons of average treatments for the degree of appreciation of jams.

\begin{tabular}{|c|c|c|c|}
\hline Samples & Differences in means between the possible pairs & Deviation value at $p \leq 0.05$ & Groups \\
\hline \multirow{4}{*}{ DJ $\mathrm{NaCl} 0.625 \%(1)$} & $(1)-(5)=4.8^{*}$ & 1.59 & \multirow{4}{*}{ A } \\
\hline & $(1)-(4)=3^{*}$ & 1.56 & \\
\hline & $(1)-(3)=2.5^{*}$ & 1.51 & \\
\hline & $(1)-(2)=1.8^{*}$ & 1.43 & \\
\hline \multirow{3}{*}{ DJ $\mathrm{NaCl} 0.3125 \%(2)$} & $(2)-(5)=3^{*}$ & 1.56 & \multirow{3}{*}{ B } \\
\hline & $(2)-(4)=1.2$ & 1.51 & \\
\hline & $(2)-(3)=0.7$ & 1.43 & \\
\hline \multirow{2}{*}{ DJ $\mathrm{NaCl} 1.25 \%(3)$} & $(3)-(5)=2.3^{*}$ & 1.51 & \multirow{2}{*}{ B } \\
\hline & $(3)-(4)=0.5$ & 1.43 & \\
\hline DJW (4) & $(4)-(5)=1.8^{*}$ & 1.43 & $\mathrm{~B}$ \\
\hline DJ $\mathrm{NaCl} 2.5 \%(5)$ & - & - & $\mathrm{C}$ \\
\hline
\end{tabular}

DJW: desamerized jam with water; DJ: desamerized jams. *Significant at $p \leq 0.05 . \mathrm{A}, \mathrm{B}$, and C: the homogeneous groups.

averages to calculate the deviation values of each pair. If the difference between the pairs of averages is greater than the value of the calculated deviation, the difference between the averages is significant at the given significance level. The deviation values are calculated based on the number of averages between the two averages tested, when the averages are placed in the order of size.

To calculate the Duncan test, the processing averages were placed in descending order as shown in Table 7.

To compare the means of this example, the deviation values for a range of 5, 4, 3, and 2 mean were calculated with the following equation:

$$
\text { deviation value }=Q \sqrt{\frac{A S(E)}{t}}
$$

where $t$ is the number of individual responses used to calculate each average.
The values of $Q$ are given from the table of critical values for the Duncan multiple comparisons test $(p \leq 0.05)$. When the mean difference is greater than the deviation value, the difference between these two means is, therefore, significant. The significant differences between averages were presented using letters.

The results show that the tasters significantly preferred the DJ $\mathrm{NaCl} 0.625 \%$ to all the other samples and liked DJ $\mathrm{NaCl} 0.3125 \%$, DJ $\mathrm{NaCl} 1.25 \%$, and $\mathrm{DJ} \mathrm{NaCl} 2.5 \%$ in comparison with DJW in the same way (Table 8 ).

\section{Conclusion}

The present work aims to study the influence of desamerization of the mesocarpe on the chemical composition and the sensorial quality of the bitter orange jam. Salt, heat, and water are considered as driving elements in the operation of 
desamerization process. The results of the physicochemical parameters and the chemical composition of the jams show that desamerization decreases acidity, sugars, protein, and bioactive compound levels (vitamin C, carotenoids, and polyphenols) and increases the ash rate. The desamerized jams presented a low content of antioxidants compared to the bitter jam and fresh product. But, regardless of the degradation of total phenolics and some antioxidants, the present results suggest that desamerized jam made from the fruit Bigarade still remain good sources of bioactive compounds with antioxidant potential in the diet.

Regarding the sensory analysis of the jams, the results show that the DJW presents the same bitterness as the bitter jam and that the salt significantly reduces the bitterness of the jams. The hedonic analysis shows that the tasters preferred significantly the DJ $\mathrm{NaCl} 0.625 \%$ to all the other samples.

\section{Data Availability}

The data used to support the findings of this study are available from the corresponding author upon request.

\section{Conflicts of Interest}

The authors declare that they have no conflicts of interest.

\section{Acknowledgments}

The authors are grateful to the Algerian Ministry of Higher Education and Scientific Research for the financial support and also thank Dr. Latreche khaled at the Faculty of Science, M'Hamed Bougara University, Boumerdes, Algeria, for his helpful revision of the manuscript.

\section{References}

[1] L. Carmona, L. Zacarías, and M. J. Rodrigo, "Stimulation of coloration and carotenoid biosynthesis during postharvest storage of 'Navelina' orange fruit at $12^{\circ} \mathrm{C}$," Postharvest Biology and Technology, vol. 74, pp. 108-117, 2012.

[2] Y. C. Wang, Y. C. Chuang, and Y. H. Ku, "Quantization of bioactive compounds in citrus fruits cultivates in Taiwan," Food Chemistry, vol. 102, no. 4, pp. 1163-1171, 2006.

[3] C. I. Cheigh, E. Y. Chung, and M. S. Chung, "Enhanced extraction of flavanones hesperidin and narirutin from Citrus unshiu peel using subcritical water," Journal of Food Engineering, vol. 110, no. 3, pp. 472-477, 2012.

[4] J. A. Manthey and K. Grohmann, "Phenols in Citrus peel byproducts: concentration sof hydroxycinnamates and polymethoxylated flavones in citrus peel molasses," Journal of Agricultural and Food Chemistry, vol. 49, no. 7, pp. 32-68, 2001.

[5] O. Benavente-García and J. Castillo, "Update on uses and properties of citrus flavonoids: new findings in anticancer, cardiovascular, and anti-inflammatory activity," Journal of Agricultural and Food Chemistry, vol. 56, no. 15, pp. 6185$6205,2008$.

[6] A. Susser, The Great Citrus Book: A Guide with Recipes, Ten Speed Press, Berkeley, CA, USA, 1997.
[7] O. A. Ashaye and T. O. Adeleke, "Quality attributes of stored Roselle jam," International Food Research Journal, vol. 16, pp. 363-371, 2009.

[8] AOAC, Official Methods of Analysis, Association of Official Analytical Chemists, Washington, DC, USA, 16th edition, 1995.

[9] AOAC, Official Methods of Analysis, Association of Official Analytical Chemists, Washington, DC, USA, 17th edition, 2000.

[10] M. C. Carrez, "Défécation du lait pour le dosage du lactose par les liqueurs cupriques, 1909," Pharmaceutical Chemistry Journal, vol. 30, pp. 36-37, 1909.

[11] M. Dubois, "Colorimetric method for determination of sugars and related substances," Analytical Chemistry, vol. 28, no. 3, pp. 350-356, 1956.

[12] C. S. Chidan Kumar, R. Mythily, R. Venkatachalapathy, and S. Chandraju, "Biomimic conversion of Maida (polysaccharides) to reducing sugars by acid hydrolysis and its estimation using standard methods," International Food Research Journal, vol. 21, no. 2, pp. 523-526, 2014.

[13] J. L. Multon, Techniques d'Analyses et de Contrôle dans les Industries Agroalimentaires, Vol. 4, Tec et Doc- Lavoisier, Paris, France, 1991.

[14] M. M. Bradford, "A rapid and sensitive method for the quantification of microgram quantities of protein utilizing the principle of protein-dye binding," Analytical Biochemstry, vol. 72, no. 1-2, pp. 248-254, 1976.

[15] AOAC, Official Methods of Analysis, Association of Official Analytical Chemists, Washington, DC, USA, 17th edition, 2002.

[16] Anonyme, TP Méthodes d'Analyses Alimentaires, Faculté des Sciences d'ingénieur, Université M’hamed Bouguara, Algérie, 2015.

[17] AOAC, Official Methods of Analysis of AOAC International, Association of Official Analytical Chemists, Washington, DC, USA, 16th edition, 1997.

[18] K. J. Meyers, C. B. Watkins, M. P. Pritts, and R. H. Liu, "Antioxydant and antiproliferative activities of strawberries," Journal of Agricultural and Food Chemistry, vol. 51, no. 23, pp. 6887-6892, 2003.

[19] K. Ba, E. Tine, J. Destain, N. Cisse, and P. Thonart, "Etude comparative des composés phénoliques, du pouvoir antioxydant de différentes variétés de sorgho sénégalais et des enzymes amylolytiques de leur malt. Biotechnologie, agronomie," Société et Environnement, vol. 14, pp. 131-139, 2010.

[20] T. Bahorun, B. Gressier, F. Trotin et al., "Oxygen species scavenging activity of phenolic extracts from hawthorn fresh plant organs and pharmaceutical preparations," ArzneimittelForschung, vol. 46, no. 11, pp. 1086-1108, 1996.

[21] A. Kumaran and R. J. Karunakaran, "Activity-guided isolation and identification of free radical-scavenging components from an aqueous extract of Coleus aromaticus," Food Chemistry, vol. 100, no. 1, pp. 356-361, 2007.

[22] A. Kumaran and R. J. Karunakaran, "In vitro antioxidant activities of methanol extracts of Phyllanhtus species from India," LWT-Food Science and Technology, vol. 40, no. 2, pp. 344-352, 2007.

[23] M. Oyaizu, "Studies on product of browning reaction prepared from glucose amine," Japanese Journal of Nutrition, vol. 44, no. 6, pp. 307-315, 1986.

[24] W. Brand-Williams, M. E. Cuvelier, and C. Berset, "Use of free radical method to evaluate antioxidant activity," LWT - Food Science and Technology, vol. 28, no. 1, pp. 25-30, 1995.

[25] B. M. Watts, G. L. Ylimaki, L. E. Jeffery, and L. G. Elias, Méthodes de base Pour l'Évaluation Sensorielle des Aliments, CRDI, Ottawa, ON, Canada, 1991. 
[26] J. Bretaudeau and Y. Fauré, Atlas d'Arboriculture Fruitière, Tec et Doc, Paris, France, 1992.

[27] F. Karadeniz, "Main organic acid distribution of authentic citrus juice in Turkey," Turkish Journal of Agriculture and Forestry, vol. 28, pp. 267-271, 2004.

[28] A. Olugbenga Olufemi, O. Grace Oluwaseun, O. Modupe Elizabeth, and O. Funmilayo Grace, "Functional jam production from blends of banana, pineapple and watermelon pulp," International Journal of Food Science and Biotechnology, vol. 3, no. 1, pp. 7-14, 2018.

[29] P. G. Crandall and L. Wicker, "Pectin internal gel strength: theory, measurement and methodology," ACS Symposium Series, pp. 88-102, American Chemical Society, Washington, DC, USA, 1986.

[30] H. Ellouze, A. Belkacem, and B. Rekik, "Variation in physicochemical and sensory quality of sour orange (Citrus aurantium L.) marmalade from the Cap Bon region in North-East Tunisia," Fruits, vol. 66, no. 5, pp. 315-325, 2011.

[31] M. Al-Farsi, C. Alasalvar, A. Morris, M. Baron, and F. Shahidi, "Compositional and sensory characteristics of three native sun-dried date (Phoenix dactylifera L.) varieties grown in Oman," Journal of Agricultural and Food Chemistry, vol. 53, no. 19, pp. 7586-7591, 2005.

[32] M. J. Esteve, A. Frigola, C. Rodrigo, and D. Rodrigo, "Effect of storage period under variable conditions on the chemical and physical composition and colour of Spanish refrigerated orange juices," Food and Chemical Toxicology, vol. 43, no. 9, pp. 1413-1422, 2005.

[33] S. Moufida and B. Marzouk, "Biochemical characterization of blood orange, sweet orange, lemon, bergamot and bitter orange," Phytochemistry, vol. 62, no. 8, pp. 1283-1289, 2003.

[34] D. Oakenfull, "Gelling agents," CRC Critical Reviews in Food Science and Nutrition, vol. 26, no. 1, pp. 1-25, 1987.

[35] S. Lagha-Benamrouche and K. Madani, "Phenolic contents and antioxidant activity of orange varieties (Citrus sinensis L. and Citrus aurantium L.) cultivated in Algeria: peels and leaves," Industrial Crops and Products, vol. 50, pp. 723-730, 2013.

[36] B. M. Ruiz-Rodriquez, P. Morales, and V. Fernandz-Ruiz, "Valorization of wild strawberry-tree fruits (Arbutus unedo L.) through nutritional assessment and natural production data," Food Research International, vol. 44, no. 5, pp. 12441253, 2011.

[37] M. N. Mohd Naeem, M. N. Mohd Fairulnizal, M. K. Norhayati et al., "The nutritional composition of fruit jams in the Malaysian market," Journal of the Saudi Society of Agricultural Sciences, vol. 16, no. 1, pp. 89-96, 2017.

[38] V. O. Aina, M. B. Ibrahim, M. Peter, A. A. J. Waziri-Adewumi, and M. S. Abdulsalami, "Nutrient and anti-nutritional composition of jam prepared from pineapple ananas comosus," Journal of Natural Sciences Research, vol. 2, no. 5, pp. 2224-3186, 2015.

[39] P. J. Fellows, Food Processing Technology: Principles and Practice, Wood Head Publishing, Cambridge, UK, 2000.

[40] H. Aissou, "Caractérisation et comparaison de trois types de pulpes (orange: Citrus sinensis, citron limon, pamplemousse: citrus maxima) et essai de fabrication de confitures," Thèse d'ingénieur en technologie alimentaire, Université Mouloud Mammeri, Tizi Ouzou, Algerie, 2013.

[41] I. Luna-Guzman and D. M. Barrett, "Comparison of calcium chloride and calcium lactate effectiveness in maintaining shelf stability and quality of fresh-cut cantaloupes," Postharvest Biology and Technology, vol. 19, no. 1, pp. 61-72, 2000.
[42] R. J. Antia, E. J. Akpan, P. A. Okon, and I. U. Umoren, "Nutritive and antinutritive evaluation of sweet potatoes (Ipomoea batatus) leaves," Pakistan Journal of Nutrition, vol. 5, no. 2, pp. 166-168, 2006.

[43] E. Whitney and S. Rolfes, Understanding Nutrition, Thompson Wadsworth Publishing Company, Belmont, CA, USA, 10th edition, 2005.

[44] A. M. E. Sulieman, K. M. Y. Khodari, and Z. A. Salih, "Extraction of pectin from lemon and orange fruits peels and its utilization in jam making," International Journal of Food Science and Nutrition Engineer, vol. 3, no. 5, pp. 81-84, 2013.

[45] G. Kansci, B. B. Koubala, and I. M. Lape, "Effect of ripening on the composition and the suitability for jam processing of different varieties of mango (Mangifera indica)," African Journal of Biotechnology, vol. 2, no. 9, pp. 301-306, 2003.

[46] N. Ghanem, D. Mihoubi, N. Kechaou, and N. Boudhrioua, "Microwave dehydration of three citrus peel cultivars: effect on water and oil retention capacities, color, shrinkage and total phenols content," Industrial Crops and Products, vol. 40, pp. 167-177, 2012.

[47] J. Eke-Ejiofor and F. Owuno, "The physico-chemical and sensory properties of jackfruit (Artocarpus heterophilus) jam," International Journal of Nutrition and Food Sciences, vol. 2, no. 3, pp. 149-152, 2013.

[48] Anonyme, Forum futura-sciences: les forums de la science, biologie; précipitation des protéines, 2010, http://forums.futurasciences.com/biologie/428724-precipitation-proteines.html.

[49] F. A. Ayaz, A. Kadioglu, and A. Dogru, "Soluble sugar composition of Elaeagnus Angustifolia var. orientalis (L.) Kuntze (Russian olive)," Fruit Turk Journal of Botany, vol. 23, pp. 349-354, 1999.

[50] M. Igual, E. Garcia-Martinez, M. M. Camacho, and N. Martinez-Navarrete, "Jam processing and storage effects on $\beta$-carotene and flavonoids content in grapefruit," Journal of Functional Foods, vol. 5, pp. 736-744, 2013.

[51] N. Touati, M. P. Tarazona-Diaz, E. Aguayo, and H. Louaileche, "Effect of storage time and temperature on the physicochemical and sensory characteristics of commercial apricot jam," Food Chemistry, vol. 145, pp. 23-27, 2014.

[52] F. A. Ayaz, M. Kucukislamoglu, and M. Reunanen, "Sugar, non-volatile and phenolic acids composition of strawberry tree (Arbutus unedo L. var. ellipsoidea) fruits," Journal of Food Composition and Analysis, vol. 13, no. 2, pp. 171-177, 2000.

[53] C. D. May and G. Stainsby, "Factors affecting pectin gelation," in Gums and Stabilisers for the Food Industry, G. O. Phillips, D. J. Wedlock, and P. A. Williams, Eds., pp. 515-523, Elsevier Applied Science, London, UK, 1986.

[54] S. Gorinstein, O. Martin-Belloso, Y. S. Parck et al., "Comparison of some biochemical characteristics of different citrus fruits," Food Chemistry, vol. 74, no. 3, pp. 309-315, 2001.

[55] O. Iordanescu, E. Alexa, M. Roxana, and P. Mariana-Atena, "Bioactive compounds and antioxidant properties at different maturity stages of apple cultivars from Romania," Journal of Food, Agriculture and Environment, vol. 10, no. 1, pp. 147-151, 2012.

[56] V. Raghu, K. Platel, and K. Srinivasan, "Comparison of ascorbic acid content of Emblica officinalis fruits determined by different analytical methods," Journal of Food Composition and Analysis, vol. 20, no. 6, pp. 529-533, 2007.

[57] P. Dupaigne, La Désamérisation des Produits d'Agrumes par voie Enzymatique, Institut Français des Auditeurs et Contrôleurs Internes, France, 1969.

[58] B. Tanwar, B. Andallu, and S. Chandel, "Influence of processing on physicochemical and nutritional composition of 
Psidium Guajava L. (guava) products," International Journal of Agriculture and Food Science Technology, vol. 5, no. 2, pp. 47-54, 2014.

[59] Y. C. Wang, Y. C. Chuang, and H. W. Hsu, "The flavonoid, carotenoid and pectin content in peels of citrus cultivated in Taiwan," Food Chemistry, vol. 106, no. 1, pp. 277-284, 2008.

[60] A. V. Rao and L. G. Rao, "Carotenoids and human health," Pharmacological Research, vol. 55, no. 3, pp. 207-216, 2007.

[61] R. Guimarães, L. Barros, J. C. M. Barreira, M. João Sousa, A. M. Carvalho, and I. Ferreira, "Targeting excessive free radicals with peels and juices of citrus fruits: grapefruit, lemon, lime and orange," Food and Chemical Toxicology, vol. 48, no. 1, pp. 99-106, 2010.

[62] Y. Klopotek, K. Otto, and V. Bohm, "Processing strawberries to different products alters contents of vitamin C, total phenolics, total anthocyanins, and antioxidant capacity," Journal of Agricultural and Food Chemistry, vol. 53, no. 14, pp. 5640-5646, 2005.

[63] F. Benmeziane, L. Djermoune-Arkoub, A. T. Boudraa, and S. Bellaagoune, "Physicochemical characteristics and phytochemical content of jam made from melon (Cucumis melo)," International Food Research Journal, vol. 25, no. 1, pp. 133141, 2018.

[64] M. Plessi, D. Bertelli, and A. Albasini, "Distribution of metals and phenolic compounds as a criterion to evaluate variety of berries and related jams," Food chemistry, vol. 100, no. 1, pp. 419-427, 2007.

[65] B. Danijela, L. Branka, and D. Verica, "Free radical scavenging activity and phenolic content in strawberry fruit and jam," Agriculturae Conspectus Scientificus, vol. 74, no. 3, pp. 155$159,2009$.

[66] T. M. Rababah, M. A. Al-Mahasneh, I. Kilani et al., "Effect of jam processing and storage on total phenolics, antioxidant activity, and anthocyanins of different fruits," Journal of Science of Food and Agriculture, vol. 91, no. 6, pp. 1096-1102, 2011. 


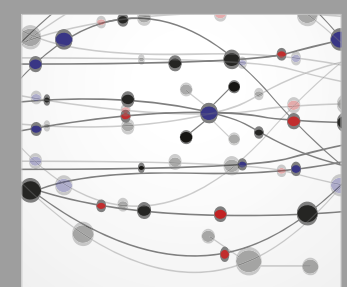

The Scientific World Journal
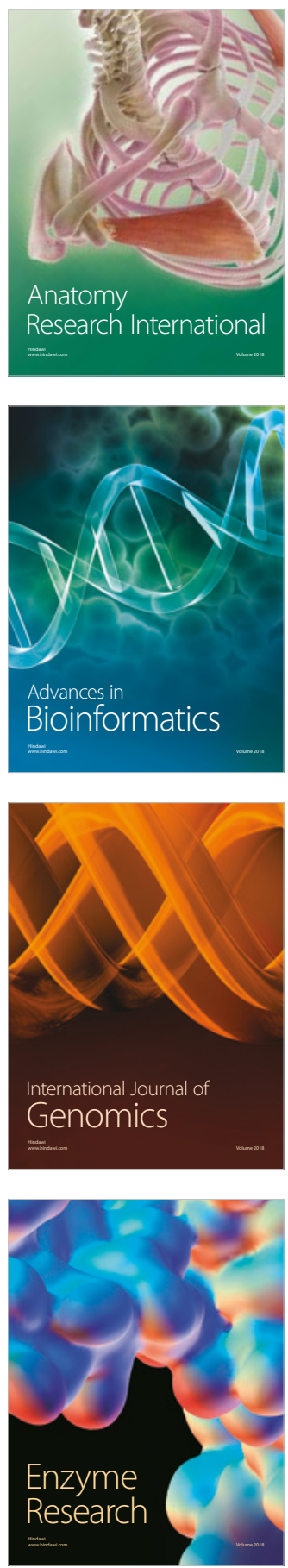
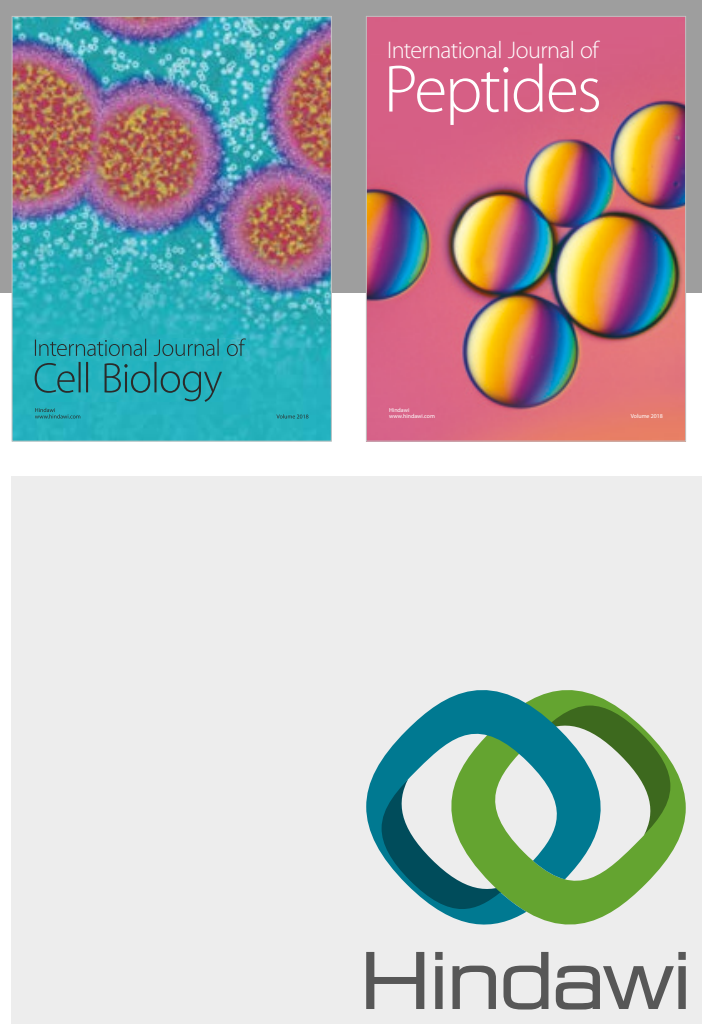

Submit your manuscripts at

www.hindawi.com
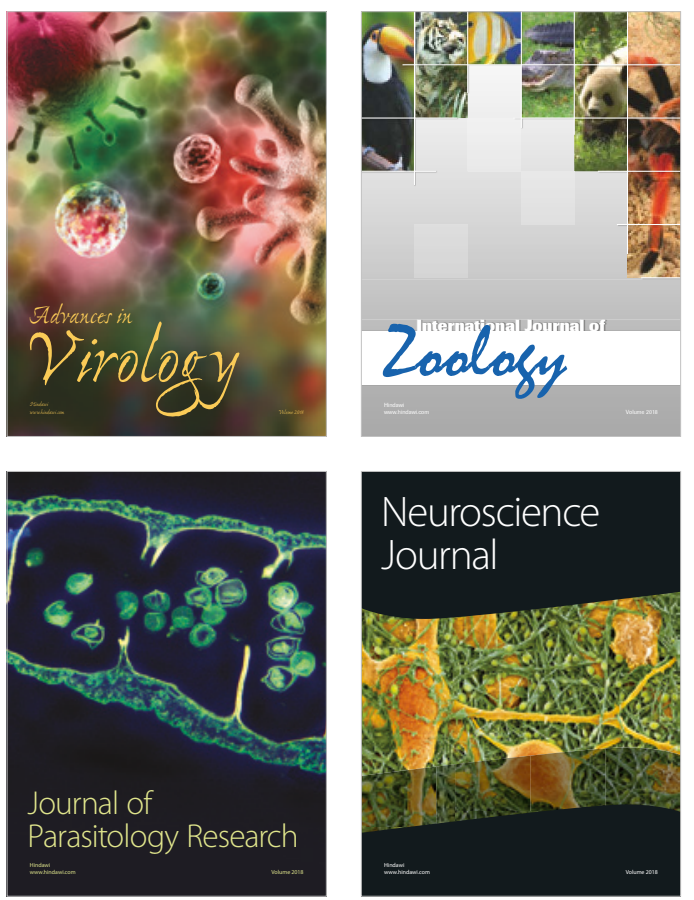
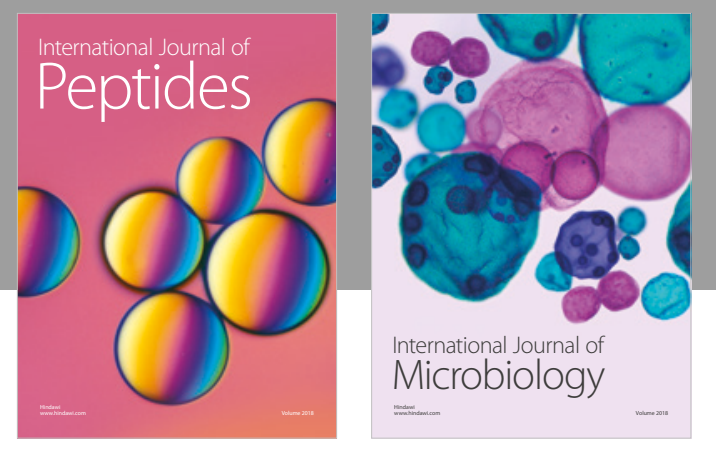

nternational Journal of Microbiology
Journal of
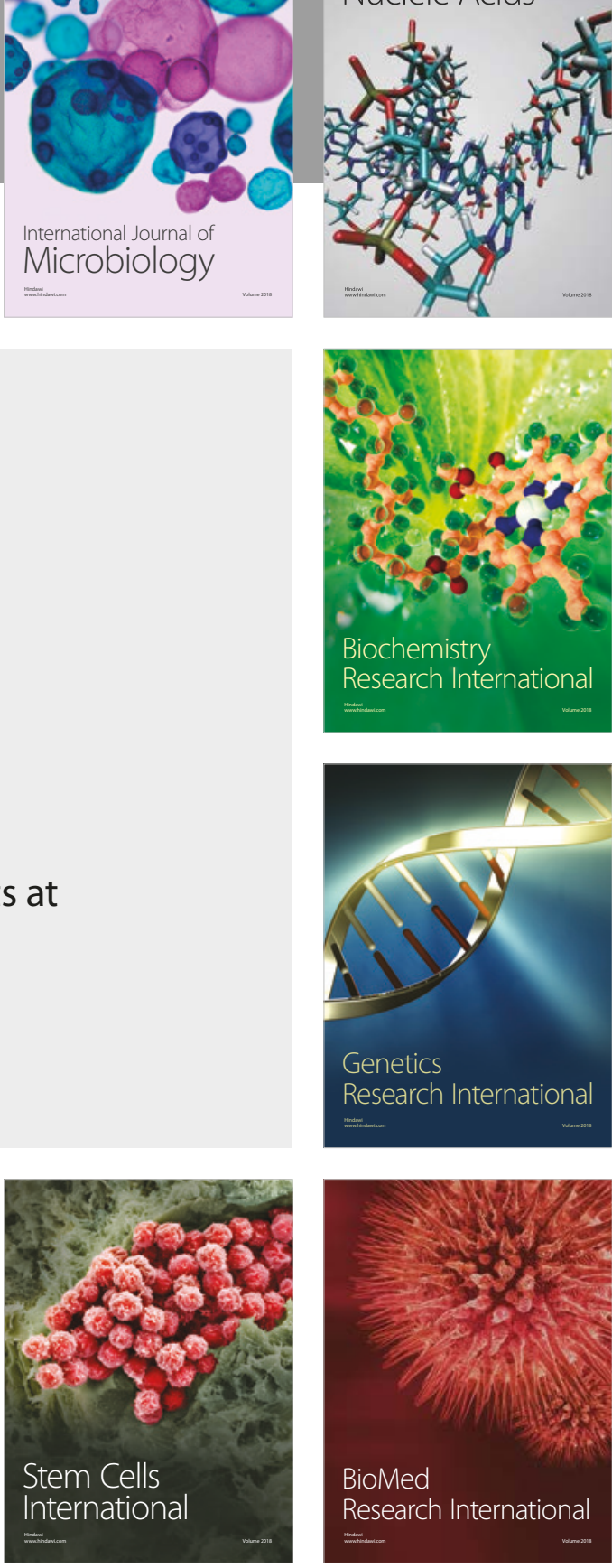
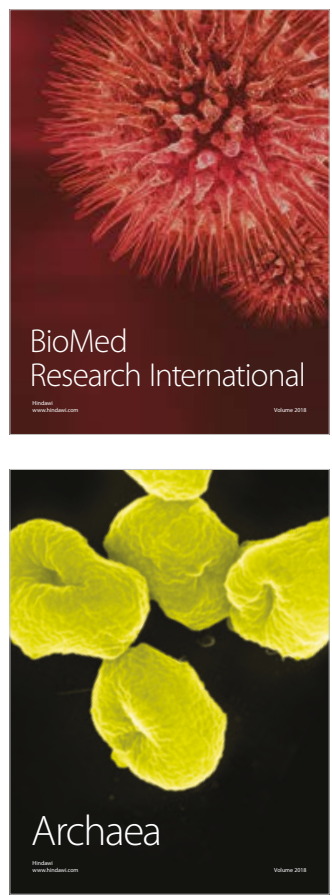